\title{
The p38 mitogen-activated protein kinase (MAPK) pathway in rheumatoid arthritis
}

\author{
$\mathbf{G ~ S c h e t t ~}^{1,2}, \mathbf{J}$ Zwerina $^{2}$, and G Firestein ${ }^{3}$ \\ ${ }^{1}$ Department of Internal Medicine III, University of Erlangen-Nuremberg, Erlangen, Germany \\ ${ }^{2}$ Division of Rheumatology, Department of Internal Medicine III, Medical University of Vienna, \\ Vienna, Austria \\ ${ }^{3}$ Division of Rheumatology, UCSD, San Diego, California, USA
}

\section{Abstract}

Chronic inflammatory processes are based on a sustained and tightly regulated communication network among different cells types. This network comprises extracellular mediators such as cytokines, chemokines and matrix-degrading proteases, which orchestrate the participation of cells in the chronic inflammatory process. The mirrors of this outside communication world are intracellular transcription factor pathways, which shuttle information about inflammatory stimuli to the cell nucleus. This review examines the function of one key signal transduction pathway of inflammation - the p38 mitogen-activated protein kinases (p38MAPK). The signalling pathway is considered as crucial for the induction and maintenance of chronic inflammation, and its components thus emerge as interesting molecular targets of small molecule inhibitors for controlling inflammation. This review not only summarises the current knowledge of activation, regulation and function of the p38MAPK pathway but also examines the role of this pathway in clinical disease. It gives an overview of current evidence of p38MAPK activation in inflammatory arthritis and elaborates the key molecular determinants which contribute to $\mathrm{p} 38 \mathrm{MAPK}$ activation in joint disease.

Communication between plasma membrane receptors and the nucleus allows cells to respond to environmental danger signals. Rapid and adequate transduction of this information is critical for appropriate cell reactions and survival. Intracellular messengers act as couriers of information from the outside world to the genes inside the nucleus. Without such molecules, genes would be "blind", like a person sitting in a room with no windows and doors, entirely deprived from external information. In real life, however, genes must be turned on quickly upon environmental changes.

One of these key sensors of cellular stress is the mitogen-activated protein kinase p38 (p38MAPK), which links inflammatory as well as environmental stress to transcription factors, which then bind to DNA and turn on the target genes. ${ }^{1} 2$ Transduction is accomplished by a cascade of activation steps involving sequential kinases linking the plasma membrane level with the transcription factor level (fig 1). p38MAPK is the most downstream signalling step before the transcription factor level and part of a greater family of proteins, the MAPKs, which share similar organisation structure. Whereas, p38MAPK and c-Jun N-terminal kinase (JNK) are mainly regulated by extracellular stress factors, the third pathway, extracellular signalrelated kinases (ERK) is preferentially a target for mitogenic stimuli. In this review, we will

Correspondence to: Professor G Schett, Department of Internal Medicine III, University of Erlangen, D-91054 Erlangen, Germany;

Georg.Schett@uk-erlangen.de.

Competing interests: None declared. 
focus on the p38MAPK cascade. Other papers have previously described the other two MAPK pathways, ERK und JNK, in rheumatic disease. ${ }^{3} 4$

\section{INDUCTION OF THE P38MAPK PATHWAY}

p38MAPK is not a single protein but comprises four different isoforms termed p38MAPK $\alpha$, $\beta,-\gamma$ and $-\delta$, which will be later discussed in more detail. Importantly, all isoforms are serinethreonine protein kinases that share the common phosphorylation motif TGY. Upon activation p38MAPK faces dual phosphorylation at threonine 180 and tyrosine $182 .{ }^{5}$ Inflammatory stimuli, such as lipopolysaccharide (LPS), tumour necrosis factor (TNF) and interleukin-1 (IL1) are the major inducers of p38MAPK. The fact that LPS induces p38MAPK led to the first description of this molecule, because p38MAPK was originally identified as an LPSactivated gene. ${ }^{5}$ Thus initial research focused on the clinical role of p38MAPK in septic shock, by virtue of its role in LPS-mediated induction of inflammatory cytokines such as TNF. ${ }^{5} 6 \mathrm{TNF}$ itself also activates p38MAPK by engaging type I TNF receptor. ${ }^{7} 8$ Downstream activation of p38MAPK then allows TNF to transduce its inflammatory message to the target organ-for example, the synovial membrane. TNF-mediated activation is also relevant in vivo because systemic TNF overexpression in mice leads to activation of p38MAPK in the inflamed joints. ${ }^{8}$ Moreover, this kinase not only integrates inflammatory stimuli but also signals heat stress, osmotic shock, ultraviolet light and cytotoxic chemicals. ${ }^{1} 2$ The activity of p38MAPK is tightly regulated by phosphatases such as mitogen-activated protein kinase phosphatase-1 (MKP-1), dephosphorylating p38MAPK. ${ }^{9}$ Interestingly, MKP-1 is strongly upregulated by glucocorticoids, suggesting that part of the anti-inflammatory properties of these drugs is based on p38MAPK inhibition. ${ }^{10} 11$ Regulation of MKP-1 by glucocorticoids has also been demonstrated in synovial fibroblasts from patients with rheumatoid arthritis (RA). ${ }^{12}$

In view of the presence of several different stress factors in the synovium, activation of the p38MAPK pathway in joints affected by RA is conceivable. Typically, proinflammatory cytokines are chronically increased in RA, which appears to be critical for p38MAPK activation in human RA. ${ }^{13}$

\section{FIRST STEP: ACTIVATION OF MAP KINASE KINASE KINASES (MAPKKK)}

Plasma membrane receptors are linked to the most upstream kinase (mitogen-activated protein kinase kinase kinase, MAPKKK or MEKK) in the by small GTPases of the $\rho$ family, such as Ras, Rac, $\rho$ or Cdc $42 .{ }^{14}$ GTPases such as $\rho$ and Ras appear to be involved in chronic synovial inflammation because both regulate synovial fibroblast proliferation. ${ }^{15} 16$ Moreover, inhibition of Ras also ameliorates adjuvant arthritis of rats. ${ }^{17}$ Ras is expressed in the synovium of RA; however, whether Ras is mutated in RA is controversial. ${ }^{18}$ The interaction between small GTPases and a MAPKKK leads to activation of a three-step kinase cascade that starts with the phosphorylation of a MAPKKK. The exact mechanism that selects a specific MAPKKK for phosphorylation of the p38MAPK pathway is unclear. In some cases the integration of signals is facilitated by the formation of signalling complexes that contain two to three kinases in series along with a structural protein. Some MEKKs such as MEKK1-4, preferentially activate downstream MAPKK, MKK4 and MKK7, which are important for the activation of JNK but not $\mathrm{p} 38 \mathrm{MAPK}$ signalling, although in some cases MKK4 can phosphorylate $\mathrm{p} 38 \mathrm{MAPK} .{ }^{19-}$ ${ }^{21}$ Among the four MEKKs, only MEKK2 protein expression is highly abundant in synovial tissue isolated from patients with RA, whereas cultivated synoviocytes express abundant MEKK1 and MEKK2 (fig 2). ${ }^{22}$ Importantly, MEKK1, MEKK2 (and TAK1) activate the JNK pathway in cultured synoviocytes as determined by in vitro kinase assay. ${ }^{22}$ One MEKK, that can only weakly affect p38MAPK, MEKK3 is only modestly expressed in the synovium. In contrast, ASK1 (also termed MEKK5), an MAPKKK that is stimulated by apoptotic stimuli

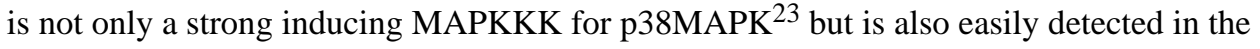


synovium of RA. ${ }^{22}$ TAK1 and MTK1 are other MAPKKKs that can induce the p38MAPK pathway by activating downstream MKK3 and MKK6. 2425 Protein and mRNA expression of TAK1 has been demonstrated in synovial tissue and cultured synoviocytes of patients with RA. $^{22}$ Among the second family of MAPKKK, the mixed lineage kinases (MLKs), MLK3 and dual leucine zipper-bearing kinase (DLK) ${ }^{26}$ can activate p38MAPK. However, MLK3 is minimally expressed in the synovium of RA and for DLK it is unknown.

\section{SECOND STEP: ACTIVATION OF MAPK KINASES (MAPKK)}

Activation of p38MAPK is accomplished by mitogen-activated protein kinases kinases (MKKs), that phosphorylate p38MAPK at amino acid residues 180 and182. MKKs are themselves subject to phosphorylation by upstream kinases (MAP3Ks), through threonine and serine residues at a specific domain of the MKK. ${ }^{27}$ Not all MKKs target p38MAPK but MKK3 and MKK6 are specifically important for the activation of p38MAPK. Studies from MKK3-/ - mice and MKK6-/- mice have shown that each of them is required for full activation of p38MAPK in cells. ${ }^{28}$ MKK3 and MKK6 share an $82 \%$ amino acid homology and expression varies with respect to tissue- and cell type. ${ }^{29} 30$ Preferential activation of either activate MKK3 or MKK6 has been described: Thus osmotic stress leads to MKK6 activation, whereas p38MAPK activation in synovial fibroblasts is preferentially triggered by MKK3 when cells are exposed to proinflammatory cytokines like TNF or IL1. ${ }^{31} 32$ Of interest the MKK3-/synoviocytes and mice responded normally to LPS challenge. These data suggest that a more favourable balance between suppression of host defence and synovial inflammation can be achieved by targeting upstream kinases. In line with an increased activation of p38MAPK in synovial tissue of RA, MKK3 and MKK6 are also activated in the joint of patients with RA.

33 Phospho-MKK expression is found mainly in the synovial lining layer, which is the subcompartment in which p38MAPK activation also is preferentially found. In contrast, synovial tissue of osteoarthritis (OA) shows only very limited phosphorylation of MKK3/6, although both MKKs can be detected in non-phosphorylated forms. Cell types in the inflamed joint that exhibit activation of MKKs are synovial fibroblasts and macrophages. ${ }^{33}$ The type of MKK which ultimately leads to activation of p38MAPK and subsequent expression of proinflammatory mediators like IL1 or IL6 as well as matrix metalloproteinases depends on the initial trigger as well as on the cell types involved. Thus, TNF-mediated activation of p38MAPK in synovial fibroblasts is predominantly MKK3-dependent, whereas stimulation by IL1 or LPS does not absolutely require MKK3 and rather involves other mechanisms such as MKK6. ${ }^{31}$ Interestingly, passive induction of KBRN arthritis in MKK3-deficient mice results in significantly less disease severity, suggesting that MKK3-induced activation of p38MAPK is a critical step in chronic arthritis (fig 3). ${ }^{31}$

\section{THIRD STEP: ACTIVATION OF THE p38 MAPK}

p38MAPK is strongly activated in the synovial membrane of RA, but not in synovial membranes of patients with degenerative joint disease. ${ }^{4}$ Roughly one-third of cells in the inflamed synovial membrane activate the p38MAPK pathway. Active p38MAPK is predominantly expressed in the endothelium of synovial microvessels and in the cells of the lining layer. These two regions are of significant importance when considering the necessity of transendothelial migration by blood-derived cells in the course of inflammation as well as the role of the lining layer in the formation of the destructive pannus (fig 4).

Apart from endothelial cells, macrophages and synovial fibroblasts are the major cell types exhibiting p38MAPK activation, which on the hand is only scarcely observed in lymphocytes. ${ }^{4}$ Similarly, activation of p38MAPK in the synovial tissue of animal models of arthritis is primarily associated with macrophages, synovial fibroblasts and endothelial cells. Osteoclasts also express activated p38MAPK at synovial invasion sites into bone in animal models of 
arthritis. ${ }^{34}$ TNF, IL1 and IL6 are potent inducers of p38MAPK in fibroblast-like synoviocytes.

\section{ISOFORMS OF P38MAPK}

So far, four different isoforms of p38MAPK have been described and knowledge of differential expression and activation of these isoforms in disease is limited ${ }^{35} 36$ Stimulating cells with LPS, leading to the discovery of the $\alpha$-isoform of p38MAPK (also termed SAPK2a), is involved in the synthesis of the proinflammatory cytokines TNF and IL1. ${ }^{5}$ Later, the $\beta$-isoform of p38MAPK (also termed SAPK2b) has been described, which shares a 75\% structural homology with $\mathrm{p} 38 \mathrm{MAPK} \alpha$ and is also activated by proinflammatory cytokines as well as environmental stress. ${ }^{37}$ Investigations in myocytes later unravelled a third isoform, p38MAPK $\gamma$ (also termed SAPK3 or ERK6), which shares a $63 \%$ structural homology with p38MAPK $\alpha .{ }^{38} 39$ And, finally, p38MAPK $\delta$ (also termed SAPK4) has been determined as a fourth isoform of p38MAPK, sharing 57\% homology with p38MAPK $\alpha$ and which, like all other forms of p38MAPKs, responds to inflammatory and toxic environmental triggers. ${ }^{40} 41$

All four p38MAPK members share activation by some but not all upstream kinases (eg, MKK6) ${ }^{42-44}$ and common molecular targets of p38MAPKs like the transcription factor ATF2. ${ }^{35} 37^{-}$ ${ }^{44}$ Proinflammatory cytokines like TNF and IL1 have the ability to stimulate all four different isoforms. ${ }^{5} 37^{-41}$ Thus, p38MAPK isoforms share several key functions. However, there are also differences among the isoforms with respect to $(a)$ mode of activation; $(b)$ regulation and inhibition; $(c)$ substrate specificity; and $(d)$ function, which underlie differences in the expression pattern of p38MAPK isoforms.

Selective activation is known for $\rho$ GTPase, which activates the only the $\gamma$-isoform. ${ }^{14}$ As stated above $\rho$ is important for the proliferative capacity of synovial cells. ${ }^{15}$ Activation of the $\delta$ isoform has been described for L1-retrotransposable elements in fibroblasts of patients with RA. ${ }^{45}$ Activation can also differ among the cell type: thus, vascular endothelial growth factor (VEGF) activates $\alpha$-isoform in endothelial cells; T-cell receptor signalling induces the $\alpha$-but not the $\beta$-isoform in lymphocytes; and LPS enhances the $\alpha$ - and $\delta$-isoform in granulocytes.

${ }^{46-48}$ Furthermore, there is selectivity in upstream kinases described. MKK3, for instance, does not activate the $\beta$-isoform. ${ }^{43}$ Finally, hypoxia mainly triggers activation of the $\alpha$ - and $\gamma$ isoforms, which is interesting since hypoxia-induced genes like HIF are abundantly expressed in the synovium. ${ }^{49}$

A second matter of isoform selectivity is the regulation and inhibition of p38MAPK. Thus, the most widespread class of synthetic p38MAPK inhibitors are pyridinyl imidazoles, which inhibit the p38MAPK $\alpha$ - and $\beta$-isoforms but not the $\gamma$ - and $\delta$-isoforms. ${ }^{37-40}$ These compounds are very effective in animal models of arthritis. Recent data indicate that arthritis is not attenuated in $\mathrm{p} 38 \mathrm{MAPK} \beta-/-$ mice, suggesting that activation of the $\alpha$-isoform is most important. ${ }^{50}$ It is unclear whether compounds of different structures, such as triaminotriazine anilines, bicyclic pyrazoles, benzimidazoles or phenylmethano-nenes have a different substrate pattern. ${ }^{51-54}$ Similarly, endogenous p38MAPK inhibitors such as MKP1 or MKP7 do not affect all isoforms but fail to inhibit p38MAPK $\gamma$ as well as $\mathrm{p} 38 \mathrm{MAPK} \gamma$ and $-\delta$, respectively. 5556 Expression of such endogenous inhibitors might be critical in the physiological regulation of inflammation. Moreover, these molecules are substrates of glucocorticoids, thereby mediating part of their anti-inflammatory effects. ${ }^{10}$ Finally, also, specific inhibition of the $\beta$ isoform is known by histone deacetylase. ${ }^{57}$

Variable substrate specificity is another form of isoform-selective function. Whereas all isoforms affect ATF2, MAPKAP2, which is actually another kinase, is only phosphorylated by the $\alpha$ - and $\beta$-isoforms. ${ }^{35} 37^{-40} 4243$ MAPKAP2 activation has been demonstrated in 
synovial fibroblast-like cells. ${ }^{58}$ On the other hand, stathmin, a protein involved in the dynamics of microtubules, is a substrate for the $\gamma$ - and $\delta$-isoforms. ${ }^{59}$ Interestingly, stathmin expression is seen in blood vessels, where it potentially participates in endothelial migration and the organisation of smooth muscle cells. ${ }^{59}$ Furthermore, specific substrates for the $\gamma$-isoform are scaffolding proteins containing PDZ motifs, which are involved in membrane trafficking and sorting of receptors, ion channels and other signalling proteins for endothelial and smooth muscle cell. ${ }^{60}$

p38MAPK isoform selectivity can also be based on the differences in the function of the various isoforms and can vary depending on the cell lineage. Thus, p38MAPK $\alpha$ specifically induces the synthesis of proteases such as stromelysin (MMP3) or collagenase-1 (MMP1), which are important for mediating cartilage damage in RA. ${ }^{61}$ Moreover, the $\alpha$-isoform can engage proteins in cell cycle arrest, such as $\mathrm{p} 21$, a CDK inhibitor. p38MAPK $\beta$ functions as a survival protein, inducing heat shock protein 70 , and a potent anti-apoptotic factor induced in the synovial membrane of patients with RA. ${ }^{62}$ Maintaining cell survival is considered to be a key feature of p38MAPK $\beta$ activation. ${ }^{62} 63$ Conversely, p38MAPK $\gamma$ is involved in myocyte differentiation, regulating proteins such as syntrophin, a synapse-associated protein. ${ }^{64}$ In contrast, p38MAPK $\delta$ is important for differentiation of keratinocytes as well as microtubule organisation, which might be important in the organisation of synovial microvessels. ${ }^{59} 65$

Recently, expression and activation of all four p38MAPK isoforms has been assessed in RA synovial tissue (fig 5). Among the four different isoforms of p38MAPK, the $\alpha$ - and $\gamma$-isoforms are the ones most abundantly expressed in the inflamed synovial tissue of patients with RA. As shown for the activated form of p38MAPK, expression of each of the isoforms except the $\delta$-isoform is virtually confined to endothelium and the synovial lining layer, the metabolically most active compartment in the synovium. ${ }^{66}$ The sublining layer including the perivascular regions, which is located in between the lining and the synovial microvessels, is almost negative for each of the p38MAPK isoforms but does express other MAPK kinase families such as ERK and JNK, as demonstrated previously. ${ }^{4}$ Endothelial p38MAPK expression is dominated by the $\gamma$-isoform but also relevant amounts of p38MAPK $\alpha$ and $-\beta$ are found. Only p38MAPK $\delta$ is not found in the endothelium but in myofibrocytes within the wall of synovial microvessels. Importantly, expression of p38MAPK $\delta$ has also been observed at sites of tissue destruction in patients with RA. ${ }^{45}$ Within the lining layer, the $\alpha$ - and $\gamma$-isoforms dominate in macrophages, the $\beta$ - and $\gamma$-isoform in fibroblasts and the $\delta$-isoform in granulocytes. Synovial lymphocytes express little or no p38MAPK. With respect to differential activation of p38MAPK isoforms it was observed that the $\alpha$ - and $\gamma$-isoforms are the ones that are predominantly activated in the inflamed tissue in vivo, whereas activation of p38MAPK $\beta$ is not common and phosphop38MAPK $\delta$ is not found in the synovial membrane. Whether other sites such as the invasion front, where p38MAPK $\delta$ expression has been observed, or the bone marrow next to synovial inflammation, show a different activation pattern remains to be determined.

\section{TARGET MOLECULES DOWNSTREAM OF P38MAPK}

p38MAK is involved in regulation of Hsp27 and MAPKAP2 and several transcription factors including ATF2, STAT1, the Max/Myc complex, MEF2, ELK1 and indirectly CREB via activation of MSK1. ${ }^{35} 37^{-40} 42^{-44}$ Interaction with these transcription factors is a crucial determinant of cellular responses after $\mathrm{p} 38 \mathrm{MAPK}$ activation. One of the key target molecules of $\mathrm{p} 38 \mathrm{MAPK}$ is MAPKAP2, which can be phosphorylated by $\mathrm{p} 38 \mathrm{MAPK} \alpha$ and $-\beta$. MAPKAP2 is essential for the biosynthesis of TNF upon LPS challenge. ${ }^{67}$ MAPKAP2 activation has been observed in synovial fibroblasts upon stimulation of the p38MAPK pathway. ${ }^{58}$ Blockade of p38MAPK in arthritis models in vivo leads to reduced activation of the downstream target MAPKAP2, suggesting that MAPKAP2 is a key downstream target molecule of p38MAPK 
in inflammatory joint disease. ${ }^{68}$ Interestingly, MAPKAP2-deficient mice are resistant to collagen-induced arthritis. ${ }^{69}$

\section{ROLE OF P38MAPK IN SYNOVIAL INFLAMMATION}

The mechanisms of gene regulation are complex and can include both transcriptional and translational events as well as alterations in mRNA stability. One major group of target genes for p38MAPK activation are proinflammatory cytokines such as TNF, IL1 and IL6. ${ }^{5} 6$ Regulation of these inflammatory mediators is thus a major function of p38MAPK, which influences the balance of pro- and anti-inflammatory mechanisms and ultimately determines whether an environmental trigger leads to a physiological self-limited inflammatory response or causes chronic inflammatory disease. Selective blockade of TNF, IL1 or IL 6 can control disease by inhibiting joint inflammation and structural damage, indicating that an imbalanced cytokine production is a key event in RA. ${ }^{70}$ The regulatory role of p38MAPK on cytokine production as well as the role of p38MAPKs as important intracellular messengers of the same cytokines provide the rationale to develop specific synthetic inhibitors. Such compounds indeed have anti-inflammatory properties in experimental animal models of arthritis and have faced difficulties in early-phase clinical trials, mainly owing to toxicity. ${ }^{67} 71^{-76}$ Inhibition of p38MAPK in animal models leads to reduced inflammation, which correlates with reduced expression of cytokines such as IL1, IL6 and RANKL. ${ }^{67}$ Upon inhibition of p38MAPK, formation of synovial inflammatory tissue is generally reduced and no disproportional effect on specific cell lineages was noted; rather, the quantity of synovial cellularity was significantly reduced. This points to a general inhibition of synovial inflammation by p38MAPK blockade rather than specific effects on certain cell types, and suggests that p38MAPK activation is a critical factor determining severity of synovial inflammation. In contrast to pharmacological inhibition of p38MAPK, which probably affects more than one isoform of p38MAPK, the selective genetic deletion of the $\beta$-isoform is not sufficient to inhibit experimental arthritis. ${ }^{50}$

Other functions of p38MAPK besides regulating proinflammatory cytokine expression probably also regulate synovitis. The role of p38MAPK in the control of cell cycle and apoptosis ${ }^{77}$ the regulation of oxidative processes by inducing nitric oxide synthethase induction ${ }^{71} 78$ and neutrophil activation ${ }^{79}$ are examples of such activities. The relative contributions of each are not known (fig 6).

\section{ROLE OF P38MAPK IN CARTILAGE DAMAGE}

Cartilage damage is a hallmark of RA. It is based on increased proteoglycan loss as well as attachment and invasion of inflammatory tissue into the cartilage, which leads to its structural disintegration. Production of matrix metalloproteinases (MMPs) by synovial tissue appears to be a key prerequisite for synovial tissue to invade and destroy cartilage. ${ }^{80} 81$ Synthesis of MMPs is regulated through multiple MAPK families, including p38MAPK, suggesting that blockade of p38MAPK might have structural benefit in arthritis. ${ }^{82} 83$

Indeed, data from animal models of arthritis suggest that p38MAPK activation might be especially important for the destructive features of arthritis since p 38 inhibitors strongly reduce cartilage degradation. ${ }^{67}$ It is uncertain, whether this effect is directly through p38MAPKdependent regulation of MMP expression or an indirect effect due to lower expression of proinflammatory cytokines, especially IL1, which is a key inducer of MMPs (fig 6).

\section{ROLE OF P38MAPK IN INFLAMMATORY BONE LOSS}

Inflammatory bone destruction is also a central component of RA, as evident from the formation of local bone erosions in RA, which lead to structural damage, changed joint architecture and loss of joint function. Bone damage in arthritis results from formation of 
osteoclasts, which are derived from monocyte precursors and resorb bone. ${ }^{84-86}$ Formation of osteoclasts is modulated by the stimulation of haematopoietic precursor cells with cytokines - that is, RANKL and TNF $\alpha$, which results in p38MAPK phosphorylation. Activation of p38MAPK is thus important for osteoclast formation. ${ }^{87} 88$ This is in line with the dramatic reduction of mature osteoclasts and osteoclast precursors in the synovial tissue of experimental arthritis after p38MAPK blockade. ${ }^{67}$ As a consequence, tissue invasion into juxta-articular bone can be effectively blocked by the use of p38MAPK inhibitors. In contrast, deregulation of p38MAPK signalling, such as found it is found in CD44-/- mice when challenged with $\mathrm{TNF} \alpha$, leads to increased osteoclast formation and increased bone resorption. ${ }^{34}$ The resulting osteoclasts are increased in number and size owing to a decreased expression of MKP-1, which is a major regulatory molecule of the p38MAPK (fig 6). ${ }^{34}$

\section{ROLE OF P38MAPK IN ENDOTHELIAL FUNCTION DURING INFLAMMATION}

Activation of p38MAPK in synovial microvessels may reflect autocrine, paracrine or even endocrine activation by proinflammatory cytokines. VEGF also makes use of p38MAPK to communicate mitogenic stimuli to endothelial cells, which are essential for the synovial microvessel proliferation in the newly formed inflammatory tissue. ${ }^{89}$ Activation of p38MAPK is critical for several different functions of endothelial cells such as $(a)$ chemoattraction; $(b)$ vasodilatation; and $(c)$ angiogenesis. Chemoattraction is a particularly critical event in synovial inflammation, since a majority of cells in the inflamed synovium migrate from the blood stream and have passed the endothelial barrier. p38MAPK regulates adhesion molecule expression, such as E-selectin and VCAM-1 on endothelial cells, which regulates rolling and adhesion of leucocytes on the endothelium before transmigrating to the inflamed tissue. ${ }^{90} 91 \mathrm{Also}$, molecules involved in chemoattraction such as MCP-1 are regulated by p38MAPK. ${ }^{92}$ Vasodilatation is the second key response of the endothelium and depends on p38MAPK. Nitric oxide (NO) synthetase is a central determinant of vasodilatation through regulating the formation of $\mathrm{NO}$ and a target gene of p38MAPK. NO-induced vasodilatation of blood vessels enables increased blood flow within the inflamed tissue and facilitates the trafficking of leucocytes to these sites. Thirdly, p38MAPK is involved in the signalling of angiogenic stimuli as outlined above. Angiogenic effects mediated by p38MAPK depend at least in part of the activation of ETS1 transcription factor (fig 6).

\section{SUMMARY}

The "cytokine era" of rheumatic disease is closely linked to a more detailed insight into the signalling processes involved in these diseases. Without engaging these molecules, cytokines would be unable to exert their proinflammatory, regulatory, mitogenic or chemoattractive properties that participate in chronic inflammation. p38MAPK is one of three MAPK cascades which are key signalling components of inflammatory disease. Over the past years there has been greatly increased insight into the expression, regulation and pathophysiological function of the components of the p38MAPK signalling cascade in inflammatory joint disease. Current data suggest that stress kinases govern a variety of processes in the synovial tissue of the inflamed joint. These new insights are important to judge in the rational selection of therapeutic targets in order to inhibit inflammation and tissue destruction in rheumatic diseases.

\section{Acknowledgments}

Funding: Supported by the SFB423 of the Deutsche Furschungsgemein-Schaft.

\section{REFERENCES}

1. Cohen DM. Mitogen-activated protein kinase cascades and the signaling of hyperosmotic stress to immediate early genes. Comp Biochem Physiol 1997;117:291-299. 
2. Johnson GL, Lapadat R. Mitogen-activated protein kinase pathways mediated by ERK, JNK, and p38 protein kinases. Science 2002;298:1911-1912. [PubMed: 12471242]

3. Sweeney SE, Firestein GS. Signal transduction in rheumatoid arthritis. Curr Opin Rheumatol 2004;16:231-237. [PubMed: 15103250]

4. Schett G, Tohidast-Akrad M, Smolen JS, Schmid BJ, Steiner CW, Bitzan P, et al. Activation, differential localization, and regulation of the stress-activated protein kinases, extracellular signalregulated kinase, c-JUN N-terminal kinase, and p38 mitogen-activated protein kinase, in synovial tissue and cells in rheumatoid arthritis. Arthritis Rheum 2000;43:2501-2512. [PubMed: 11083274]

5. Lee JC, Laydon JT, McDonnell PC, Gallagher TF, Kumar S, Green D, et al. A protein kinase involved in the regulation of inflammatory cytokine biosynthesis. Nature 1994;372:739-746. [PubMed: 7997261]

6. Beyaert R, Cuenda A, Vanden Berghe W, Plaisance S, Lee JC, Haegeman G, et al. The p38/RK mitogen-activated protein kinase pathway regulates interleukin- 6 synthesis response to tumor necrosis factor. EMBO J 1996;15:1914-1923. [PubMed: 8617238]

7. Ferrero E, Zocchi MR, Magni E, Panzeri MC, Curnis F, Rugarli C, et al. Roles of tumor necrosis factor p55 and p75 receptors in TNF-alpha-induced vascular permeability. Am J Physiol Cell Physiol 2001;281:C1173-C1179. [PubMed: 11546653]

8. Gortz B, Hayer S, Tuerck B, Zwerina J, Smolen JS, Schett G. Tumour necrosis factor activates the mitogen-activated protein kinases p38alpha and ERK in the synovial membrane in vivo. Arthritis Res Ther 2005;7:R1140-R1147. [PubMed: 16207331]

9. Theodosiou A, Ashworth A. MAP kinase phosphatases. Genome Biol 2002;3:3009.

10. Kassel O, Sancono A, Kratzschmar J, Kreft B, Stassen M, Cato AC. Glucocorticoids inhibit MAP kinase via increased expression and decreased degradation of MKP-1. EMBO J 2001;20:7108-7116. [PubMed: 11742987]

11. Lasa M, Abraham SM, Boucheron C, Saklatvala J, Clark AR. Dexamethasone causes sustained expression of mitogen-activated protein kinase (MAPK) phosphatase 1 and phosphatase-mediated inhibition of MAPK p38. Mol Cell Biol 2002;22:7802-7811. [PubMed: 12391149]

12. Toh ML, Yang Y, Leech M, Santos L, Morand EF. Expression of mitogen-activated protein kinase phosphatase 1, a negative regulator of the mitogen-activated protein kinases, in rheumatoid arthritis: up-regulation by interleukin-1beta and glucocorticoids. Arthritis Rheum 2004;50:3118-3128. [PubMed: 15476200]

13. Feldmann M, Brennan FM, Foxwell BM, Maini RN. The role of TNF alpha and IL-1 in rheumatoid arthritis. Curr Dir Autoimmun 2001;3:188-199. [PubMed: 11791466]

14. Marinissen MJ, Chiariello M, Gutkind JS. Regulation of gene expression by the small GTPase Rho through the ERK6 (p38 gamma) MAP kinase pathway. Genes Dev 2001;15:535-553. [PubMed: 11238375]

15. Nakayamada S, Kurose H, Saito K, Mogami A, Tanaka Y. Small GTP-binding protein Rho-mediated signaling promotes proliferation of rheumatoid synovial fibroblasts. Arthritis Res Ther 2005;7:476484.

16. Kitasato H, Noda M, Akahoshi T, Okamoto R, Koshino T, Murakami Y, et al. Activated Ras modifies the proliferative response of rheumatoid synovial cells to TNF-alpha and TGF-alpha. Inflamm Res 2001;50:592-597. [PubMed: 11822784]

17. Yamamoto A, Fukuda A, Seto H, Miyazaki T, Kadono Y, Sawada Y, et al. Suppression of arthritic bone destruction by adenovirus-mediated dominant-negative Ras gene transfer to synoviocytes and osteoclasts. Arthritis Rheum 2003;48:2682-2692. [PubMed: 13130489]

18. Roivainen A, Soderstromx KO, Pirila L, Aro H, Kortekangas P, Merilahti-Palo R, et al. Oncoprotein expression in human synovial tissue: an immunohistochemical study of different types of arthritis. Br J Rheumatol 1996;35:933-942. [PubMed: 8883430]

19. Yan M, Dai T, Deak JC, Kyriakis JM, Zon LI, Woodgett JR, et al. Activation of stress-activated protein kinase by MEKK1 phosphorylation of its activator SEK1. Nature 1994;372:798-800. [PubMed: 7997270]

20. Blank JL, Gerwins P, Elliott EM, Sather S, Johnson GL. Molecular cloning of mitogen-activated protein/ERK kinase kinases (MEKK) 2 and 3. Regulation of sequential phosphorylation pathways 
involving mitogen-activated protein kinase and c-Jun kinase. J Biol Chem 1996;271:5361-5368. [PubMed: 8621389]

21. Gerwins P, Blank JL, Johnson GL. Cloning of a novel mitogen-activated protein kinase kinase kinase, MEKK4, that selectively regulates the c-Jun amino terminal kinase pathway. J Biol Chem 1997;272:8288-8295. [PubMed: 9079650]

22. Hammaker DR, Boyle DL, Chabaud-Riou M, Firestein GS. Regulation of c-Jun N-terminal kinase by MEKK-2 and mitogen-activated protein kinase kinase kinases in rheumatoid arthritis. J Immunol 2004;172:1612-1618. [PubMed: 14734742]

23. Ichijo H, Nishida E, Irie K, ten Dijke P, Saitoh M, Moriguchi T, et al. Induction of apoptosis by ASK1, a mammalian MAPKKK that activates SAPK/JNK and p38 signaling pathways. Science 1997;275:90-94. [PubMed: 8974401]

24. Takekawa M, Posas F, Saito H. A human homolog of the yeast Ssk2/Ssk22 MAP kinase kinase kinases, MTK1, mediates stress-induced activation of the p38 and JNK pathways. EMBO J 1997;16:4973-4982. [PubMed: 9305639]

25. Yamaguchi K, Shirakabe K, Shibuya H, Irie K, Oishi I, Ueno N, et al. Identification of a member of the MAPKKK family as a potential mediator of TGF-beta signal transduction. Science 1995;270:2008-2011. [PubMed: 8533096]

26. Fan G, Merritt SE, Kortenjann M, Shaw PE, Holzman LB. Dual leucine zipper-bearing kinase (DLK) activates p46SAPK and p38mapk but not ERK2. J Biol Chem 1996;271:24788-24793. [PubMed: 8798750]

27. Fanger GR, Johnson NL, Johnson GL. MEK kinases are regulated by EGF and selectively interact with Rac/Cdc42. EMBO J 1997;16:4961-4972. [PubMed: 9305638]

28. Cong F, Goff SP. c-Abl-induced apoptosis, but not cell cycle arrest, requires mitogen-activated protein kinase kinase 6 activation. Proc Natl Acad Sci USA 1999;96:13819-13824. [PubMed: 10570156]

29. Lu HT, Yang DD, Wysk M, Gatti E, Mellman I, Davis RJ, et al. Defective IL-12 production in mitogen-activated protein (MAP) kinase kinase 3 (Mkk3)-deficient mice. EMBO J 1999;18:18451857. [PubMed: 10202148]

30. Tanaka N, Kamanaka M, Enslen H, Dong C, Wysk M, Davis RJ, et al. Differential involvement of p38 mitogen-activated protein kinase kinases MKK3 and MKK6 in T-cell apoptosis. EMBO Rep 2002;3:785-791. [PubMed: 12151339]

31. Inoue T, Boyle DL, Corr M, Hammaker D, Davis RJ, Flavell RA, et al. Mitogen-activated protein kinase kinase 3 is a pivotal pathway regulating p38 activation in inflammatory arthritis. Proc Natl Acad Sci USA 2006;103:5484-5489. [PubMed: 16567640]

32. Moriguchi T, Toyoshima F, Gotoh Y, Iwamatsu A, Irie K, Mori E, et al. Purification and identification of a major activator for $\mathrm{p} 38$ from osmotically shocked cells. Activation of mitogen-activated protein kinase kinase 6 by osmotic shock, tumor necrosis factor-alpha, and H2O2. J Biol Chem 1996;271:26981-26988. [PubMed: 8900184]

33. Chabaud-Riou M, Firestein GS. Expression and activation of mitogen-activated protein kinase kinases-3 and -6 in rheumatoid arthritis. Am J Pathol 2004;164:177-184. [PubMed: 14695331]

34. Hayer S, Steiner G, Gortz B, Reiter E, Tohidast-Akrad M, Amling M, et al. CD44 is a determinant of inflammatory bone loss. J Exp Med 2005;201:903-914. [PubMed: 15781582]

35. Keesler GA, Bray J, Hunt J, Johnson DA, Gleason T, Yao Z, et al. Purification and activation of recombinant p38 isoforms alpha, beta, gamma, and delta. Protein Expr Purif 1998;14:221-228. [PubMed: 9790884]

36. Hale KK, Trollinger D, Rihanek M, Manthey CL. Differential expression and activation of p38 mitogen-activated protein kinase alpha, beta, gamma, and delta in inflammatory cell lineages. J Immunol 1999;162:4246-4252. [PubMed: 10201954]

37. Jiang Y, Chen C, Li Z, Guo W, Gegner JA, Lin S, et al. Characterization of the structure and function of a new mitogen-activated protein kinase (p38beta). J Biol Chem 1996;271:17920-17926. [PubMed: 8663524]

38. Lechner C, Zahalka MA, Giot JF, Moller NP, Ullrich A. ERK6, a mitogen-activated protein kinase involved in C2C12 myoblast differentiation. Proc Natl Acad Sci USA 1996;93:4355-4359. [PubMed: 8633070] 
39. Cuenda A, Cohen P, Buee-Scherrer V, Goedert M. Activation of stress-activated protein kinase-3 (SAPK3) by cytokines and cellular stresses is mediated via SAPKK3 (MKK6); comparison of the specificities of SAPK3 and SAPK2 (RK/p38). EMBO J 1997;16:295-305. [PubMed: 9029150]

40. Jiang Y, Gram H, Zhao M, New L, Gu J, Feng L, et al. Characterization of the structure and function of the fourth member of p38 group mitogen-activated protein kinases p38delta. J Biol Chem 1997;272:30122-30128. [PubMed: 9374491]

41. Wang XS, Diener K, Manthey CL, Wang S, Rosenzweig B, Bray J, et al. Molecular cloning and characterization of a novel p38 mitogen-activated protein kinase. J Biol Chem 1997;272:2366823674. [PubMed: 9295308]

42. Enslen H, Brancho DM, Davis RJ. Molecular determinants that mediate selective activation of p38 MAP kinase isoforms. EMBO J 2000;19:1301-1311. [PubMed: 10716930]

43. Enslen H, Raingeaud J, Davis RJ. Selective activation of p38 mitogen-activated protein (MAP) kinase isoforms by the MAP kinase kinases MKK3 and MKK6. J Biol Chem 1998;273:1741-1748. [PubMed: 9430721]

44. Kumar S, McDonnell PC, Gum RJ, Hand AT, Lee JC, Young PR. Novel homologues of CSBP/p38 MAP kinase: activation, substrate specificity and sensitivity to inhibition by pyridinyl imidazoles. Biochem Biophys Res Commun 1997;235:533-538. [PubMed: 9207191]

45. Neidhart M, Rethage J, Kuchen S, Kunzler P, Crowl RM, Billingham ME, et al. Retrotransposable L1 elemts expressed in rheumatoid arthritis synovial tissue: association with genomic hypomethylation and influence on gene expression. Arthritis Rheum 2000;43:2634-2647. [PubMed: 11145021]

46. Yashima R, Abe M, Tanaka K, Ueno H, Shitara K, Takenoshita S, et al. Heterogeneity of the signal transduction pathways for VEGF-induced MAPKs activation in human vascular endothelial cells. J Cell Physiol 2001;188:201-210. [PubMed: 11424087]

47. Hsu SC, Gavrilin MA, Tsai MH, Han J, Lai MZ. p38 mitogen-activated protein kinase is involved in Fas ligand expression. J Biol Chem 1999;274:25769-25776. [PubMed: 10464315]

48. Nick JA, Avdi NJ, Young SK, Lehman LA, McDonald PP, Frasch SC, et al. Selective activation and functional significance of p38alpha mitogen-activated protein kinase in lipopolysaccharidestimulated neutrophils. J Clin Invest 1999;103:851-858. [PubMed: 10079106]

49. Hollander AP, Corke KP, Freemont AJ, Lewis CE. Expression of hypoxia-inducible factor 1alpha by macrophages in the rheumatoid synovium: implications for targeting of therapeutic genes to the inflamed joint. Arthritis Rheum 2001;44:1540-1541. [PubMed: 11465705]

50. Beardmore VA, Hinton HJ, Eftychi C, Apostolaki M, Armaka M, Darragh J, et al. Generation and characterization of p38beta (MAPK11) gene-targeted mice. Mol Cell Biol 2005;25:10454-10464. [PubMed: 16287858]

51. Leftheris K, Ahmed G, Chan R, Dyckman AJ, Hussain Z, Ho K, et al. The discovery of orally active triaminotriazine aniline amides as inhibitors of p38 MAP kinase. J Med Chem 2004;47:6283-6291. [PubMed: 15566298]

52. Laufersweiler MJ, Brugel TA, Clark MP, Golebiowski A, Bookland RG, Laughlin SK, et al. The development of novel inhibitors of tumor necrosis factor-alpha (TNF-alpha) production based on substituted [5,5]-bicyclic pyrazolones. Bioorg Med Chem Lett 2004;14:4267-4272. [PubMed: 15261284]

53. Dombroski MA, Letavic MA, McClure KF, Barberia JT, Carty TJ, Cortina SR, et al. Benzimidazolone p38 inhibitors. Bioorg Med Chem Lett 2004;14:919-923. [PubMed: 15012994]

54. Goldstein DM, Alfredson T, Bertrand J, Browner MF, Clifford K, Dalrymple SA, et al. Discovery of S-[5-amino-1-(4-fluorophenyl)-1H-pyrazol-4-yl-]-[3-(2,3-dihydroxypropoxy)phenyl]methanone (RO3201195), an orally bioavailable and highly selective inhibtor for p38 MAP kinase. J Med Chem 2006;49:1562-1575. [PubMed: 16509574]

55. Pratt PF, Bokemeyer D, Foschi M, Sorokin A, Dunn MJ. Alterations in subcellular localization of p38 MAPK potentiates endothelin-stimulated COX-2 expression in glomerular mesangial cells. J Biol Chem 2003;278:51928-51936. [PubMed: 14530261]

56. Tanoue T, Yamamoto T, Maeda R, Nishida E. A Novel MAPK phosphatase MKP-7 acts preferentially on JNK/SAPK and p38 alpha and beta MAPKs. J Biol Chem 2001;276:26629-26639. [PubMed: 11359773] 
57. Mahlknecht U, Will J, Varin A, Hoelzer D, Herbein G. Histone deacetylase 3, a class I histone deacetylase, suppresses MAPK11-mediated activating transcription factor-2 activation and represses TNF gene expression. J Immunol 2004;173:3979-3990. [PubMed: 15356147]

58. Miyazawa K, Mori A, Miyata H, Akahane M, Ajisawa Y, Okudaira H. Regulation of interleukin-1beta-induced interleukin- 6 gene expression in human fibroblast-like synoviocytes by p38 mitogen-activated protein kinase. J Biol Chem 1998;273:24832-24838. [PubMed: 9733787]

59. Curmi PA, Andersen SS, Lachkar S, Gavet O, Karsenti E, Knossow M, et al. The stathmin/tubulin interaction in vitro. J Biol Chem 1997;272:25029-25036. [PubMed: 9312110]

60. Hasegawa M, Cuenda A, Spillantini MG, Thomas GM, Buee-Scherrer V, Cohen P, et al. Stressactivated protein kinase-3 interacts with the PDZ domain of alpha1-syntrophin. A mechanism for specific substrate recognition. J Biol Chem 1999;274:12626-12631. [PubMed: 10212242]

61. Reunanen N, Li SP, Ahonen M, Foschi M, Han J, Kahari VM. Activation of p38 alpha MAPK enhances collagenase-1 (matrix metalloproteinase (MMP)-1) and stromelysin-1 (MMP-3) expression by mRNA stabilization. J Biol Chem 2002;277:32360-32368. [PubMed: 12060661]

62. Kim HP, Wang X, Zhang J, Suh GY, Benjamin IJ, Ryter SW, et al. Heat shock protein-70 mediates the cytoprotective effect of carbon monoxide: involvement of p38 beta MAPK and heat shock factor-1. J Immunol 2005;175:2622-2629. [PubMed: 16081837]

63. Nemoto S, Xiang J, Huang S, Lin A. Induction of apoptosis by SB202190 through inhibition of p38beta mitogen-activated protein kinase. J Biol Chem 1998;273:16415-16420. [PubMed: 9632706]

64. Sabio G, Reuver S, Feijoo C, Hasegawa M, Thomas GM, Centeno F, et al. Stress- and mitogeninduced phosphorylation of the synapse-associated protein SAP90/PSD-95 by activation of SAPK3/ p38gamma and ERK1/ERK2. Biochem J 2004;380:19-30. [PubMed: 14741046]

65. Efimova T, Broome AM, Eckert RL. A regulatory role for p38 delta MAPK in keratinocyte differentiation. Evidence for p38 delta-ERK1/2 complex formation. J Biol Chem 2003;278:3427734285. [PubMed: 12810719]

66. Korb A, Tohidast-Akrad M, Cetin E, Axmann R, Smolen J, Schett G. Differential tissue expression and activation of p38 MAPK alpha, beta, gamma, and delta isoforms in rheumatoid arthritis. Arthritis Rheum 2006;54:2745-2756. [PubMed: 16947383]

67. Zwerina J, Hayer S, Redlich K, Bobacz K, Kollias G, Smolen JS, et al. Activation of p38 MAPK is a key step in tumor necrosis factor-mediated inflammatory bone destruction. Arthritis Rheum 2006;54:463-472. [PubMed: 16447221]

68. Kotlyarov A, Neininger A, Schubert C, Eckert R, Birchmeier C, Volk HD, et al. MAPKAP kinase 2 is essential for LPS-induced TNF-alpha biosynthesis. Nat Cell Biol 1999;1:94-97. [PubMed: 10559880]

69. Hegen M, Gaestel M, Nickerson-Nutter CL, Lin LL, Telliez JB. MAPKAP kinase 2-deficient mice are resistant to collagen-induced arthritis. J Immunol 2006;177:1913-1917. [PubMed: 16849504]

70. Smolen JS, Steiner G. Therapeutic strategies for rheumatoid arthritis. Nat Rev Drug Discov 2003;2:473-488. [PubMed: 12776222]

71. Badger AM, Griswold DE, Kapadia R, Blake S, Swift BA, Hoffmann SJ, et al. a selective inhibitor of mitogen-activated protein kinase, in rat adjuvant arthritis. Arthritis Rheum 2000;43:75-83.

72. Nishikawa M, Myoui A, Tomita T, Takahi K, Nampei A, Yishikawa H. Prevention of the onset and progression of collagen-induced arthritis in rats by the potent $\mathrm{p} 38$ mitogen-activated protein kinase inhibitor FR167653. Arthritis Rheum 2003;48:2670-2681. [PubMed: 13130488]

73. Wadsworth SA, Cavender DE, Beers SA, Lalan P, Schafer PH, Malloy EA, et al. RWJ 67657, a potent, orally active inhibitor of p38 mitogen-activated protein kinase. J Pharmacol Exp Ther 1999;291:680-687. [PubMed: 10525088]

74. Patten C, Bush K, Rioja I, Morgan R, Wooley P, Trill J, et al. Characterization of pristane-induced arthritis, a murine model of chronic disease: response to antirheumatic agents, expression of joint cytokines, and immunopathology. Arthritis Rheum 2004;50:3334-3345. [PubMed: 15476226]

75. Medicherla S, Ma JY, Mangadu R, Jiang Y, Zhao JJ, Almirez R, et al. A selective p38 alpha mitogenactivated protein kinase inhibitor reverses cartilage and bone destruction in mice with collageninduced arthritis. J Pharmacol Exp Ther 2006;318:132-141. [PubMed: 16597712] 
76. Revesz L, Blum E, Di Padova FE, Buhl T, Feifel R, Gram H, et al. Novel p38 inhibitors with potent oral efficacy in several models of rheumatoid arthritis. Bioorg Med Chem Lett 2004;14:3595-3599. [PubMed: 15177482]

77. Juo P, Kuo CJ, Reynolds SE, Konz RF, Raingeaud J, Davis RJ, et al. Fas activation of the p38 mitogenactivated protein kinase signalling pathway requires ICE/CED-3 family proteases. Mol Cell Biol 1997; 17:24-35. [PubMed: 8972182]

78. Chan ED, Winston BW, Uh ST, Wynes MW, Rose DM, Riches DW. Evaluation of the role of mitogenactivated protein kinases in the expression of inducible nitric oxide synthase by IFN-gamma and TNF-alpha in mouse macrophages. J Immunol 1999;162:415-422. [PubMed: 9886415]

79. Zu YL, Qi J, Gilchrist A, Fernandez GA, Vazquez-Abad D, Kreutzer DL, et al. p38 mitogen-activated protein kinase activation is required for human neutrophil function triggered by TNF-alpha or FMLP stimulation. J Immunol 1998;160:1982-1989. [PubMed: 9469462]

80. Pap T, Aupperle KR, Gay S, Firestein GS, Gay RE. Invasiveness of synovial fibroblasts is regulated by 553 in the SCID mouse in vivo model of cartilage invasion. Arthritis Rheum 2001;44:676-681. [PubMed: 11263783]

81. Muller-Ladner U, Gay S. The SCID mouse-a novel experimental model for gene therapy in human rheumatoid arthritis. Drugs Today 1999;3:379-388. [PubMed: 12973440]

82. Liacini A, Sylvester J, Li WQ, Huang W, Dehnade F, Ahmad M, et al. Induction of matrix metalloproteinase-13 gene expression by TNF-alpha is mediated by MAP kinases, AP-1, and NFkappaB transcription factors in articular chondrocytes. Exp Cell Res 2003;288:208-217. [PubMed: 12878172]

83. Suzuki M, Tetsuka T, Yoshida S, Watanabe N, Kobayashi M, Matsui N, et al. The role of p38 mitogenactivated protein kinase in IL-6 and IL-8 production from the TNF-alpha-or IL-1beta-stimulated rheumatoid synovial fibroblasts. FEBS Lett 2000;465:23-27. [PubMed: 10620700]

84. Redlich K, Hayer S, Ricci R, David JP, Tohidast-Akrad M, Kollias G, et al. Osteoclasts are essential for TNF-alpha-mediated joint destruction. J Clin Invest 2002;110:1419-1427. [PubMed: 12438440]

85. Gravallese EM, Harada Y, Wang JT, Gorn AH, Thornhill TS, Goldring SR. Identification of cell types responsible for bone resorption in rheumatoid arthritis and juvenile rheumatoid arthritis. Am J Pathol 1998;152:943-951. [PubMed: 9546355]

86. Schett G, Hayer S, Zwerina J, Redlich K, Smolen JS. Mechanisms of disease: the link between RANKL and arthritic bone disease. Nat Clin Pract Rheumatol 2005;1:47-54. [PubMed: 16932627]

87. Li X, Udagawa N, Itoh K, Suda V, Murase Y, Nishihara T, et al. p38 MAPK-mediated signals are required for inducing osteoclast differentiation but not for osteoclast function. Endocrinology 2002;143:3105-3113. [PubMed: 12130576]

88. Matsumoto M, Sudo T, Maruyama M, Osada H, Tsujimoto M. Activation of p38 mitogen-activated protein kinase is crucial in osteoclastogenesis induced by tumor necrosis factor. FEBS Lett 2000;486:23-28. [PubMed: 11108836]

89. Rosseau S, Houle F, Landry J, Huot J. p38 MAP kinase activation by vascular endothelial growth factor mediates actin reorganization and cell migration in human endothelial cells. Oncogene 1997;15:2169-2177. [PubMed: 9393975]

90. Read MA, Whitley MZ, Gupta S, Pierce JW, Best J, Davies RJ, et al. Tumor necrosis factor alphainduced E-selectin expression is activated by the nuclear factor-kappaB and c-JUN N-terminal kinase/p38 mitogen-activated protein kinase pathways. J Biol Chem 1997;272:2753-2761. [PubMed: 9006914]

91. Pietersma A, Tilly BC, Gaestel M, de Jong N, Lee JC, Koster JF, et al. p38 mitogen activated protein kinase regulates endothelial VCAM-1 expression at the post-transcriptional level. Biochem Biophys Res Commun 1997;230:44-48. [PubMed: 9020057]

92. Goebeler M, Kilian K, Gillitzer R, Kunz M, Yoshimura T, Brocker EB, et al. The MKK6/p38 stress kinase cascade is critical for tumor necrosis factor-alpha-induced expression of monocytechemoattractant protein-1 in endothelial cells. Blood 1999;93:857-865. [PubMed: 9920834] 


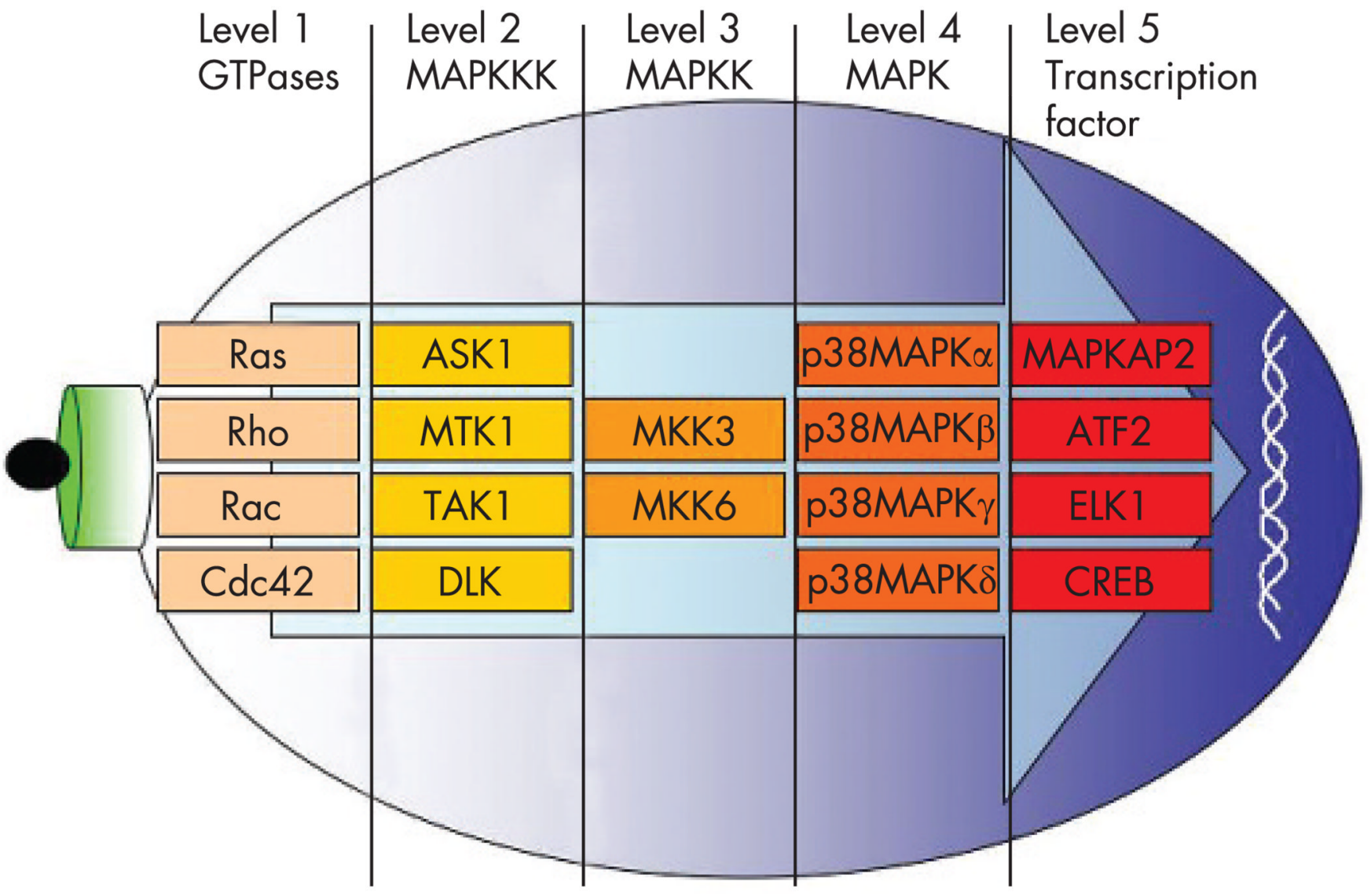

Figure 1.

Scheme of p38 mitogen-activated protein kinase (p38MAPK) activation. As a key intracellular signal transduction pathway the p38MAPK cascade links the plasma membrane (left) with the DNA (right). After activation of small GTPases (level 1), the signal is transduced by a threestep MAPK cascade (levels 2-4) before activating transcription factors (level 5). 
A

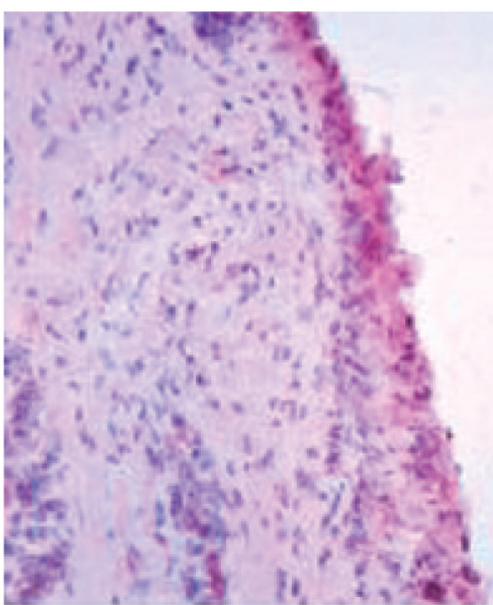

B

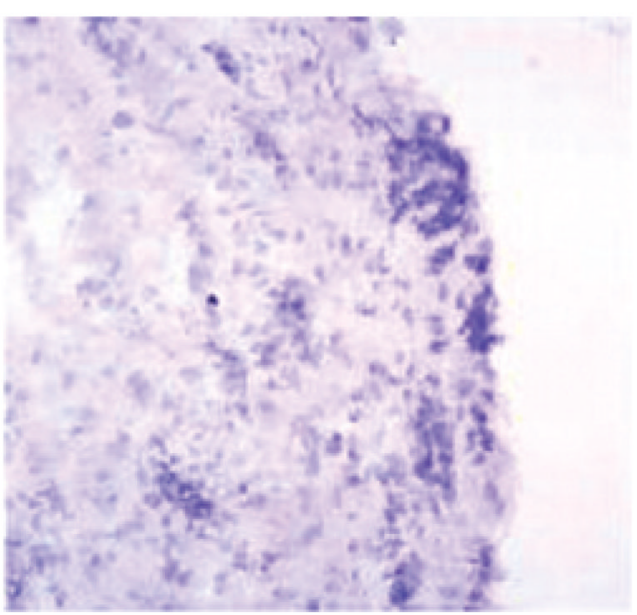

C

MEKK2

TAK 1

MEKK3

Actin

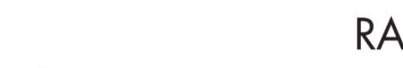

RA
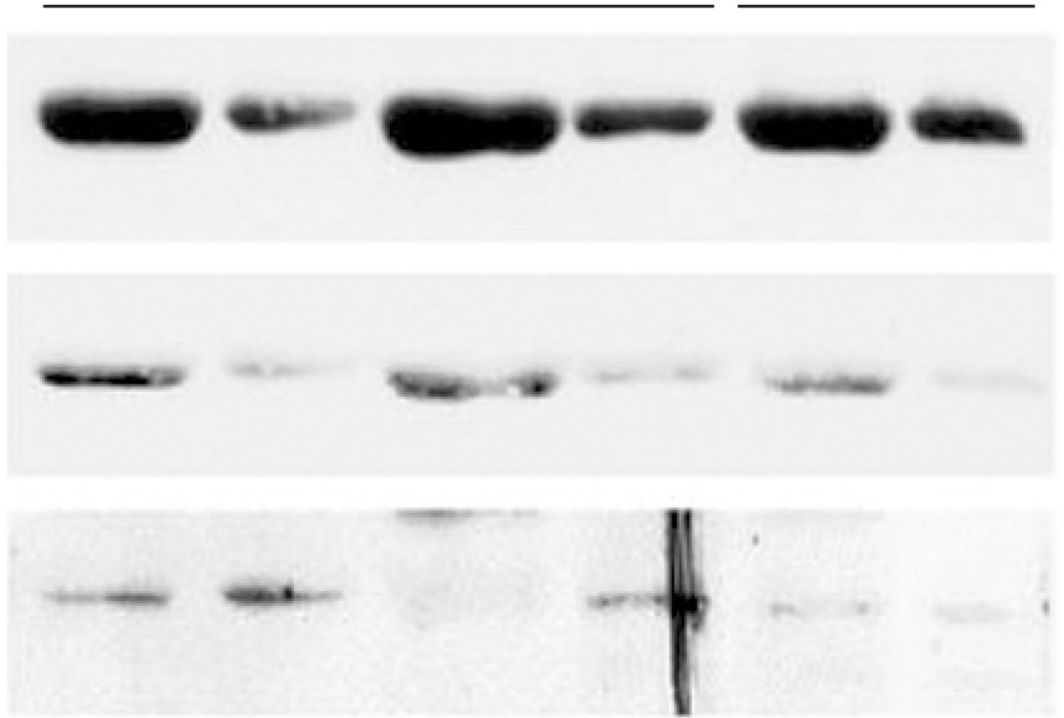

$=$

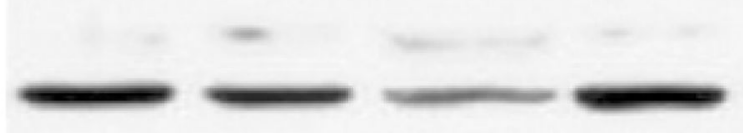

Figure 2.

Mitogen-activated protein kinase kinase kinases (MAPKKK) expression in rheumatoid arthritis (RA). (A, B) Immunostaining of the MEKK2, a MAPKKK in the synovial membrane of RA. The image depicts the lining layer and part of the synovial sublining. The lining layer shows intense pink staining for MEKK2 (A) but not with control immunoglobulin (B). (C) Immunoblots of cultivated synvovial findroblasts showing expression of the three different MAPKKK, MEKK3, TAK1 and MEKK3. 


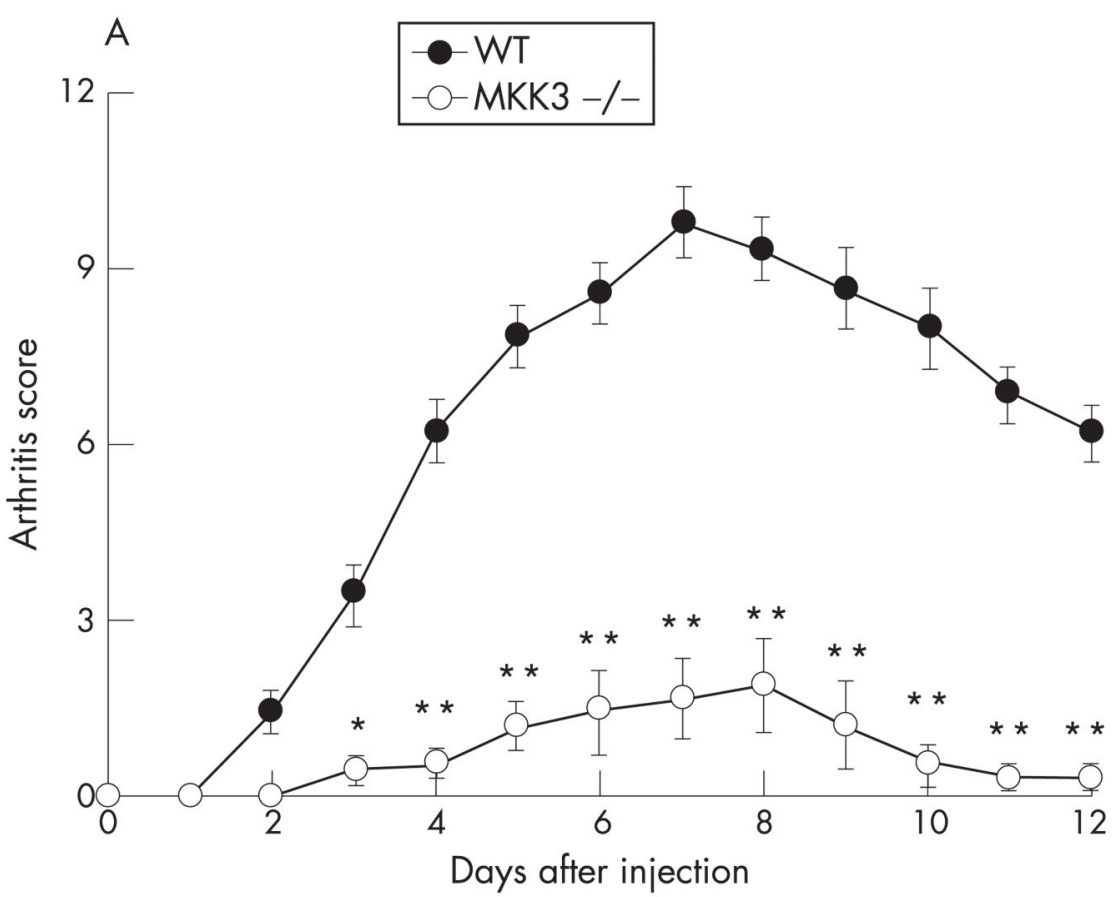

B
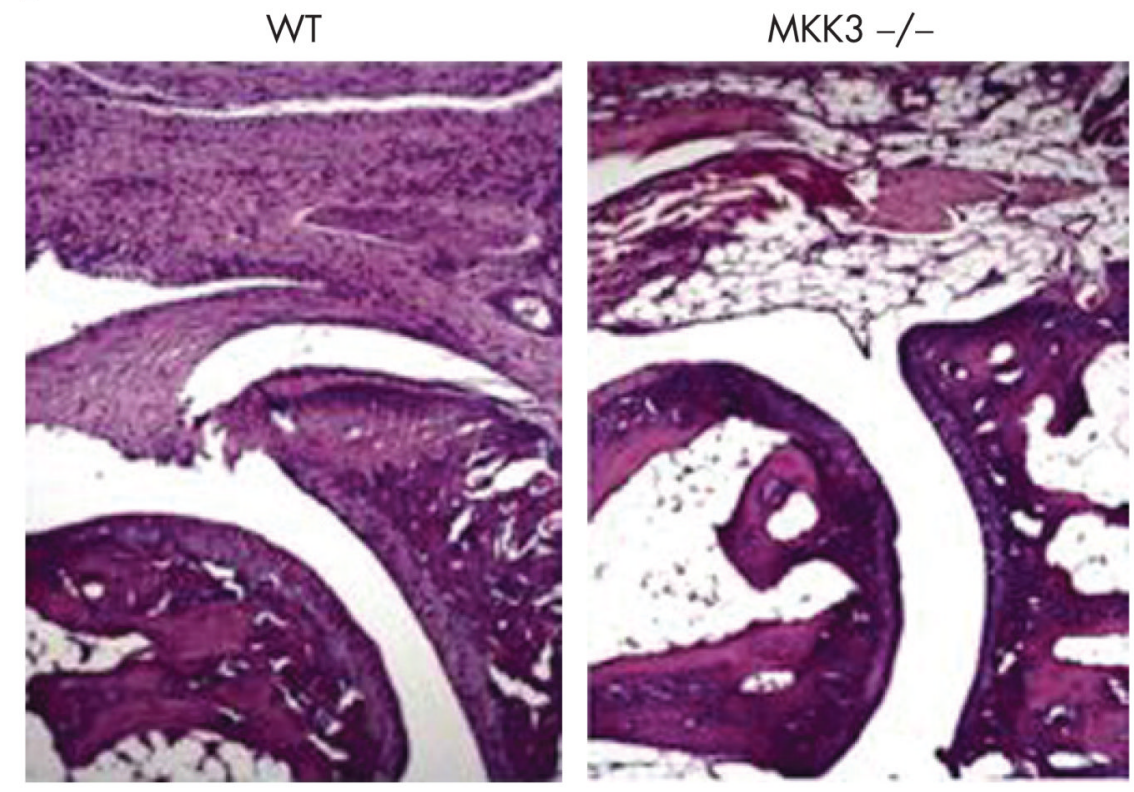

Figure 3.

The role of MKK3 in arthritis. Mice deficient for MKK3 (MKK3-/-) are almost completely resistant to the serum transfer model of arthritis. (A) Course of joint swelling in wild-type (WT) and MKK3 $-/-$ mice induced for arthritis. (B) Microphotograph of histological sections of hind paws of WT and MKK3-/- mice challenged by arthritogenic serum. 


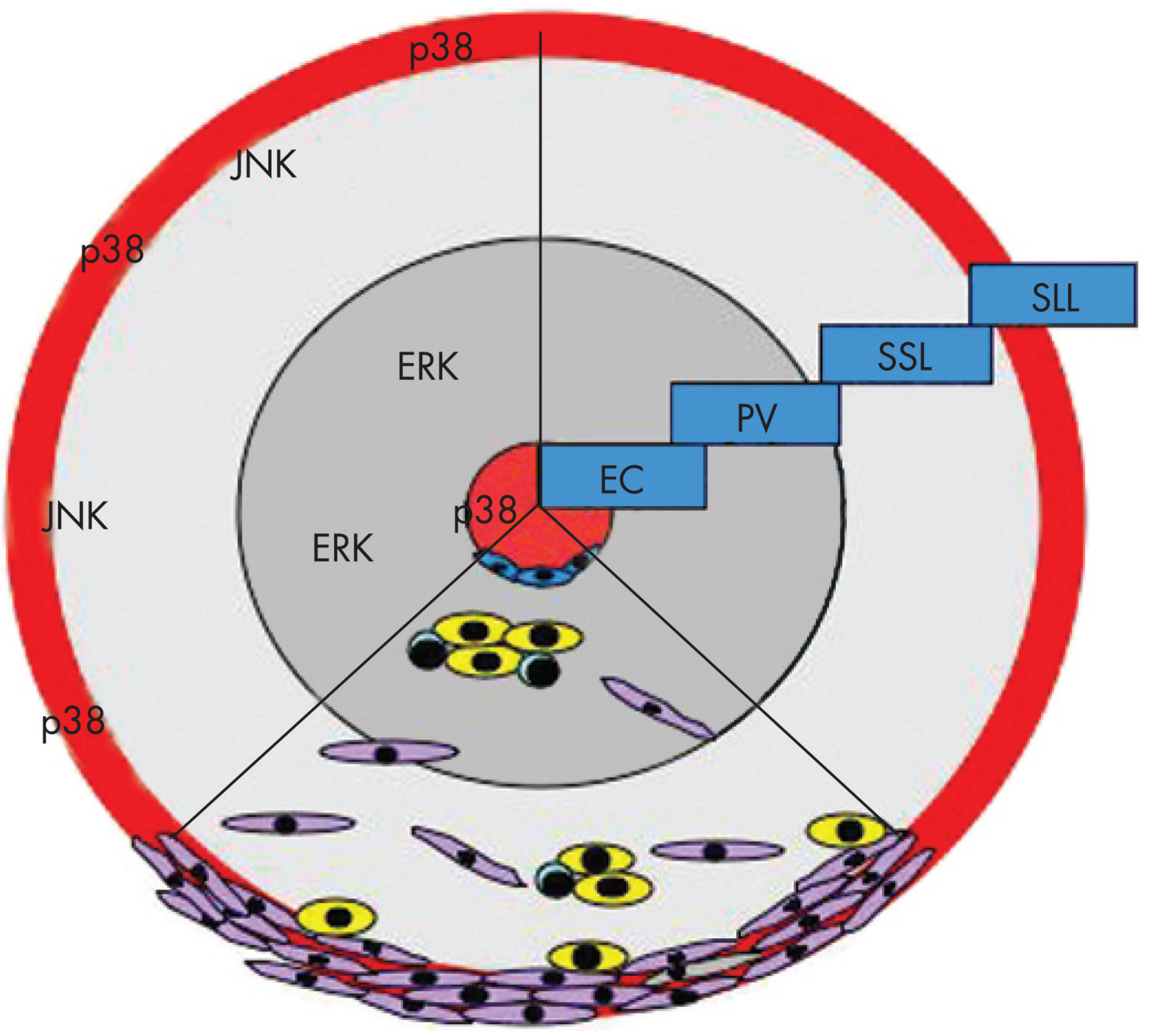

Figure 4.

Activation of p38 mitogen-activated protein kinase (p38MAPK) in rheumatoid arthritis. Activation of p38MAPK dominates in the synovial lining layer (SLL) and in endothelial cells (EC) of synovial microvessels. In contrast, the synovial sublining (SSL) and the perivascular regions (PV) are not major points of p38MAPK activation. 


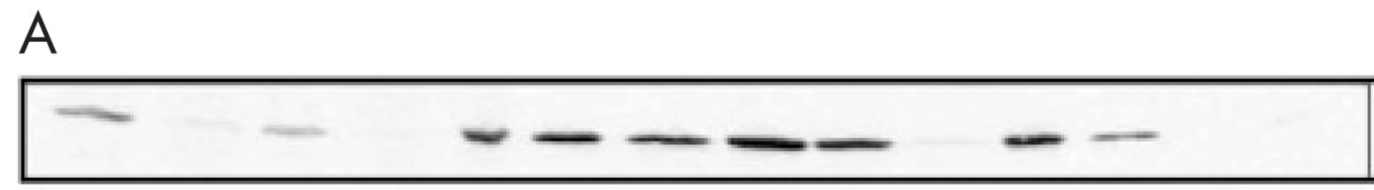

p38MAPK $\alpha$

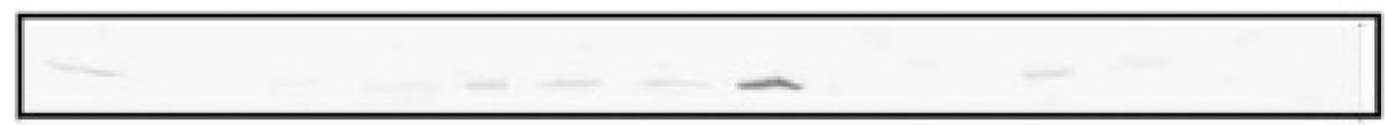

p38MAPK $\beta$

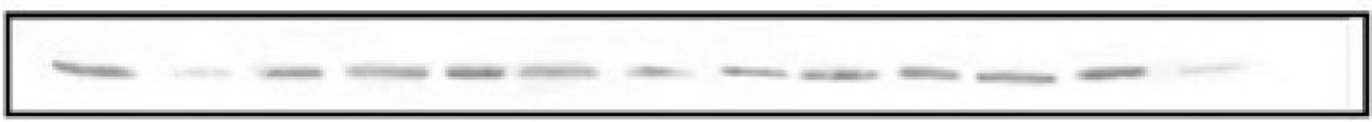

p38MAPK $\gamma$

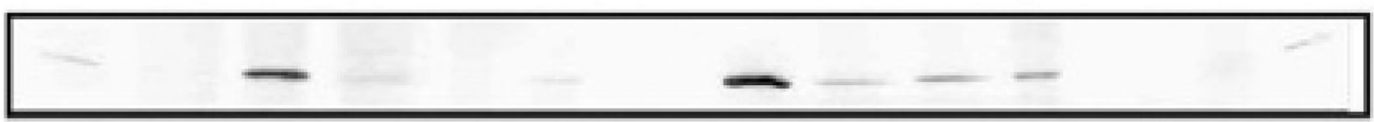

p38MAPK $\delta$

B

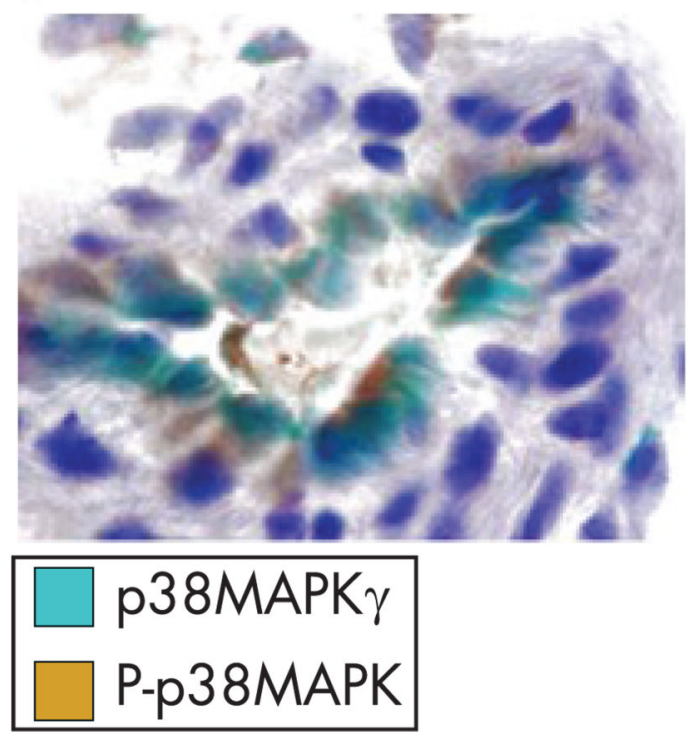

C

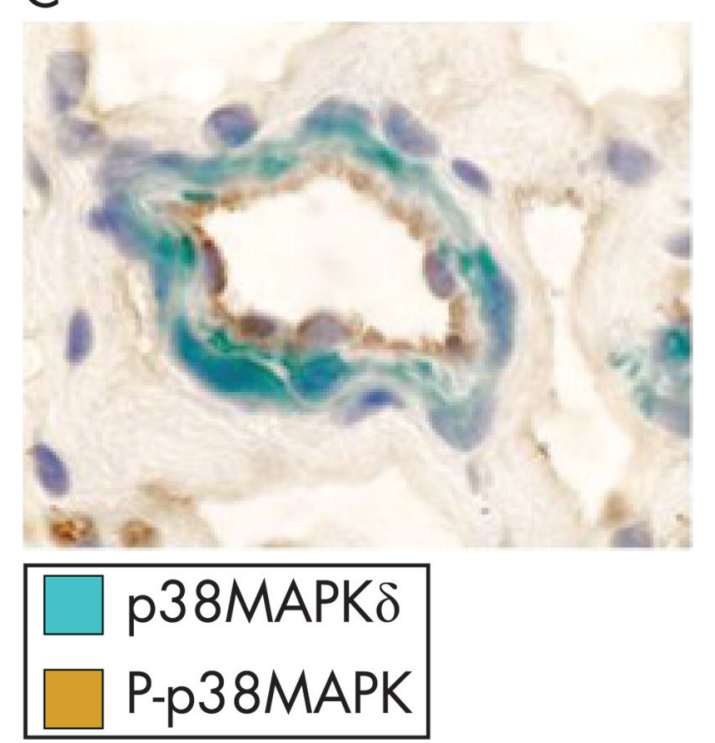

Figure 5.

Expression and activation of p38 mitogen-activated protein kinase (p38MAPK) isoforms in rheumatoid arthritis (RA). (A) Immunoblot for p38MAPK isoforms in synovial tissue extracts from patients with RA. Individual patients differ in their patterns of MAPK isoform activation. (B, C) Microphotographs of synovial microvessels stained for phosphorylated p38MAPK (brown) and p38MAPK $\gamma(\mathrm{B}$, green) or p38MAPK $\delta(\mathrm{C}$, green). 

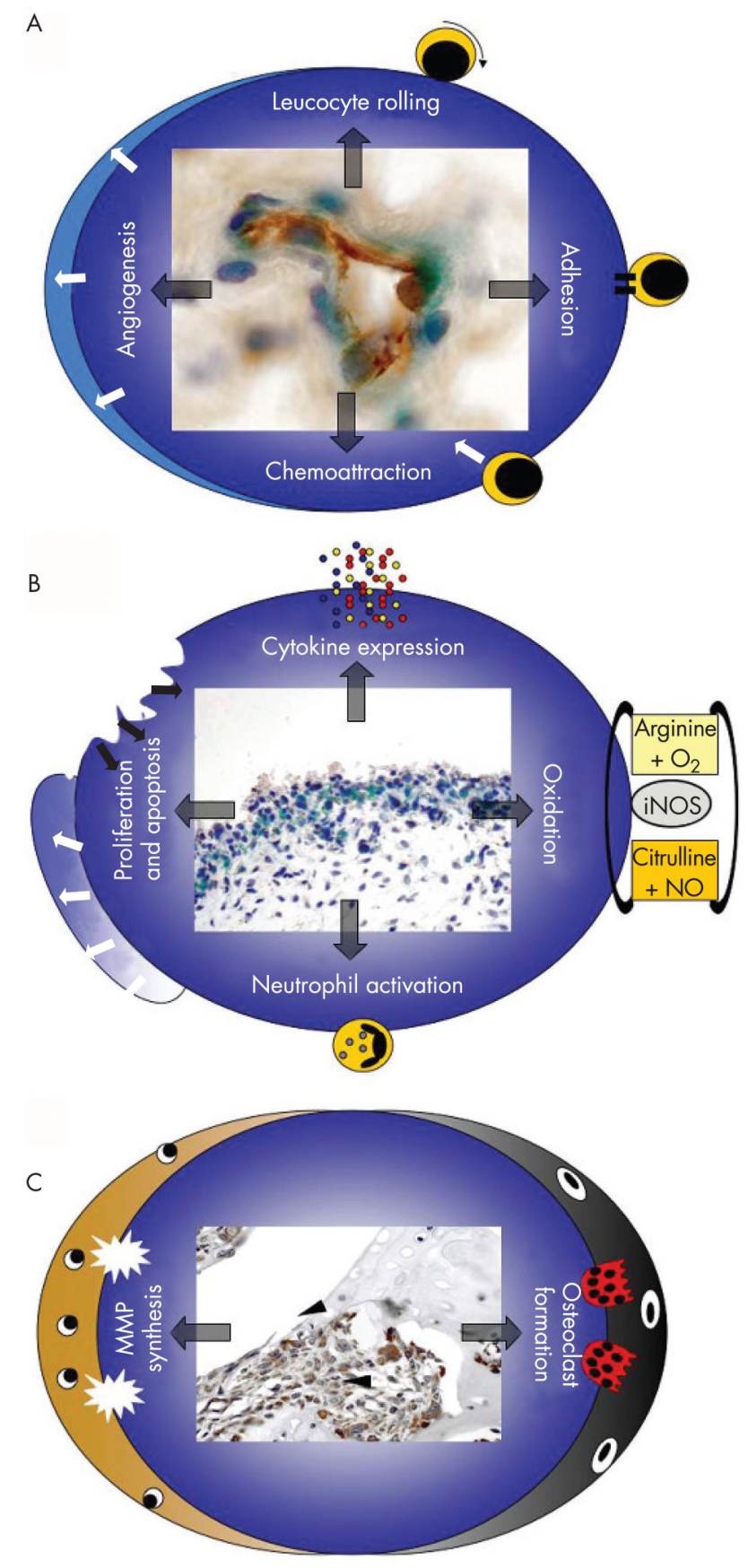

Figure 6.

Function of p38 mitogen-activated protein kinase (p38MAPK) activation in rheumatoid arthritis. Activation of p38MAPK regulates mechanisms of endothelial cell function (A), synovial inflammation (B) and bone and cartilage degradation (C). Thus, p38MAPK is involved in the rolling, activation and chemoattraction of leucocytes as well as angiogenesis. In synovial inflammation, p38MAPK is important for proinflammatory cytokine expression, oxidation processes, activation of granulocytes and cell cycle regulation. The role of p38MAPK in cartilage and bone destruction is based on its role to induce matrix metalloproteinases and activation of osteoclasts. iNOS, inducible nitric oxide synthetase. 